\title{
Strategic Positioning and Asymmetric Cost Behavior in Nepalese Enterprises
}

Dhundi Raj Bhattarai, Ph.D. *

\begin{abstract}
The purpose of this paper is to examine the association between Nepalese enterprises' choice of strategic position and their cost behavior. The research design adopted in this study consists of descriptive and causal-comparative research designs to deal with the various issues raised in this study. Secondary data has been used for this study which was collected from annual audit report of concerned organization of manufacturing and hotel industrities from fiscal year 2000/01 to 2014/15. Descriptive statistics, correlation analysis, and regression analysis are different statistical tool that has been used for this study. Cost stickiness of the enterprises pursuing a differentiation strategy is higher than that of following a cost leadership strategy. This paper contributes to the literature on cost management by explaining how strategic positioning affects firms' cost behavior using the framework of asymmetric cost behavior.
\end{abstract}

Key Words: Strategic positioning, Asymmetric cost behavior Differentiation Strategy, Cost-leadership Strategy, Cost stickiness Nepalese Enterprise

*Lecturer, Nepal Commerce Campus, TU and visiting faculty at Nepal College of Management,email: dhundibhattarai@gmail.com 


\section{Introduction}

Cost behavior is associated with learning how costs change when there is a change in an organization's level of activity. The costs which vary proportionately with the changes in the level of activity are referred to as variable costs. The costs that are unaffected by changes in the level of activity are classified as fixed costs. The understanding of cost behavior is very important for management's efforts to plan and control its organization's costs. Budgets and variance reports are more effective when they reflect cost behavior patterns. The understanding of cost behavior is also necessary for calculating a company's break-even point and for any other cost-volume-profit analysis.

Cost behavior is an essential element of implementation of generic strategies. In the traditional model of cost behavior that pervades the accounting literature, costs are described as fixed or variable with respect to changes in activity volume. Variable cost change proportionately with changes in the activity driver (Noreen, 1991), implying that the magnitude of a change in costs depends only on the extent of a change in the level of activity, not on the direction of the change. But some claim costs raise more with increase in activity volume than they fall with decreases (cooper \& Kaplan, 1998). Specially, costs are sticky if the magnitude of the increase in costs associated with an equivalent decrease in volume. Empirical research provides very little evidence about the behavior of activity costs in relation to change in activity levels. One reason for this paucity of research may be a perceived scarcity a broad based data that include the costs and relevant drivers.

In addition, prior studies have also documented that a variety of factors, such as managerial incentives and governance, can either mitigate or intensify asymmetric cost behavior. Dierynck, Landsman, and Renders (2012) document that managers increase labor costs to a smaller extent for sales increases but decrease labor costs to a larger extent for sales decreases so that their firms can meet or beat the zero earnings benchmark. Similarly, Kama and Weiss (2013) document that in the presence of incentives to meet earnings targets, managers expedite the trimming of slack resources in response to sales decreases, which results in a lower degree of cost stickiness than under normal circumstances. In contrast, Chen, Lu, and Sougiannis (2012) document those managers' empire-building behavior leads to cost stickiness and strong corporate governance mitigates such an asymmetry. 
Recent research on asymmetric cost behavior in cost accounting (e.g., Anderson, Banker, \& Janakiraman, 2003 hereafter ABJ; Weiss, 2010; Chen, et al., 2012) offers a fundamentally different potential explanation for asymmetric timeliness of earnings. Specifically, this research documents that many costs are sticky, i.e., they increase more when sales increase than they decrease when sales decrease. ABJ argue that cost stickiness arises because of two fundamental features of cost behavior: (1) many costs are determined by deliberate resource commitments made by managers, and (2) changing committed resource levels is costly and it involves adjustment costs such as hiring and firing costs for labor, or installation and disposal costs for equipment. Thus, when sales decrease, managers can choose whether to cut the committed resources, and if so, how much to cut them. Because managers take into account the adjustment costs associated with cutting resources in the current period, as well as future adjustment costs required to restore resources if sales rebound in the future, they will often retain some underutilized resources to save on these adjustment costs. Therefore, the decrease in costs will be less than proportional to the decrease in sales. On the other hand, when sales increase, managers will have to add enough resources to accommodate the increased sales.

\section{Literature review}

As a result, on average, costs will increase more for sales increases than they decrease for equivalent sales decreases, leading to cost stickiness. The asymmetric response of costs to sales changes due to stickiness further results in asymmetric behavior of earnings. Because costs enter earnings with a negative sign, cost stickiness implies that earnings should respond less to sales increases than to sales decreases. Because sales changes are positively correlated with concurrent stock returns, positive returns likely accompany sales increases, for which the relation between earnings and sales is weak.

Meanwhile, a body of literature on strategic cost management suggests that managers make deliberate decisions to align a firm's cost structure with its business strategy. Weiss (2010) examine the extent to which an organization's core competency affects its cost stickiness by using a sample of Canadian acute care hospitals. They postulate that hospital managers are unwilling to reduce costs associated with these services that are critical to hospital's mission and associated with high adjustment costs. Consistent with this conjecture, they find the existence of cost stickiness only in costs related to direct patient care, a hospital's core service. 
In contrast, this study investigates how strategic positioning affects managers' decisions about resource commitment, leading to asymmetric cost behavior. To achieve a competitive advantage, firms explicitly or implicitly pursue a competitive strategy (Porter 1996). Conceptualize competitive strategy by Porter's typology of differentiation and cost leadership (Porter, 1980; 1985; 1991). Successful differentiators need to achieve a technology leadership or create a high degree of customer intimacy (Porter, 1996). To achieve these strategic goals, differentiators make significant investments in capacity resources (e.g. human capital) specialized to their strategic needs (Peteraf, 1993). Consequently, it is costly for the differentiator to cut back on these specialized resources, because they are much less valuable in factor markets compared to the potential value they can create within the firm. On the other hand, cost leaders make efforts to achieve operational excellence through efficient operations, resulting in a lean cost structure and low adjustment costs (Porter 1980, 1996). Combining the two lines of literature about asymmetric cost behavior and business strategy, a higher degree of cost stickiness relative to cost leaders, because differentiators have to face higher adjustment costs. Furthermore, Banker, Byzalov, Ciftci, \& Mashruwala, (2013).

Banker et.al. (2013) argue that managerial expectation about future sales will affect firms' asymmetric cost behavior. Following Banker et al. (2013), managerial optimism (pessimism), operationalized by a pattern of prior period sales increases (decreases), will moderate the functional relationship between a firm's strategic position and its cost stickiness or anti-stickiness.

Differentiation and cost leadership strategy operationalized by three alternative sets of strategy measures as in Bentley, Omer, and Sharp (2012) (henceforth BOS), an adapted version of Ittner, Larcker, and Rajan (1997) and financial ratios based on Selling and Stickney (1989) separately. For parsimony, this study presents only detailed empirical results using the BOS strategy measure in principal analysis, and uses the other two strategy measures in the additional analysis to document robustness of this study. The strategy of differentiation aims to create a product or service that is seen to be unique by customers. Porter (1980) argues that by creating customer loyalty and price inelasticity this strategy erects competitive barriers to entry, provides higher margin, and reduces the power of buyers because they feel that they lack acceptable substitute products. Miller $(1986 ; 1988)$ notes that there are at least two different types of differentiation strategies: product innovation and intensive marketing or image management. 
The cost leadership strategy strives for superior efficiency in manufacturing and distributing (this is also true of the defender strategy discussed by Miles and Snow, (1978). It eschews frequent adaptation, innovation or customizing of products to meet the special needs of customer (Miles \& Snow, 1978). Although cost leadership requires creative cost trimming and perhaps benefits from related analytical activity, it calls for very little scanning and analysis of markets (Hambrick, 1982).

\section{Hypothesis development}

Cost stickiness occurs when the absolute value of the cost change is greater for an increase than a decrease in activity volume (ABJ, 2003). Correspondingly, cost antistickiness arises when, for the same level of change in sales, cost decreases are more significant for sales decreases than the cost increases are for sales increases (Weiss 2010; Banker et al., 2013). The main idea underlying asymmetric cost behavior is that costs will not mechanically increase or decrease in line with changes in sales activity in the real world, unless managers make decisions on investing in or cutting back on resource capacity (ABJ, 2003). Thus, both sticky and anti-sticky costs can be attributed to the deliberate resource commitment decisions by rational managers facing uncertain demand and various adjustment costs (Banker \& Byzalov, 2013).

Cost leaders often have an organizational arrangement of low autonomy (with tight control) and frequent reporting (White, 1986). Relative to differentiators, cost leaders can more easily increase their resources to mirror sales increases as the acquired resources are not as unique or specialized as the differentiators. Cost leaders have lower adjustment costs and maintain more flexible cost structures than differentiators. Overall, it is expected that facing sales decreases, differentiators will carry more unused capacity resources to save adjustment costs than cost leaders. Hence, the following hypothesis is tested.

H1: Cost stickiness of firms pursuing a differentiation strategy is higher than that of firms following a low cost strategy.

\section{Research methodology}

The research design adopted in this study consists of descriptive and causal-comparative research designs to deal with the various issues raised in this study. 


\subsection{Data}

Secondary data is used to measure strategic positioning and asymmetric cost behavior of Nepalese listed enterprises. The population of this study is eleven listed manufacturing and processing companies which are presely operating and four listed hotels. These are: Bottlers Nepal Ltd.(Balaju), Bottlers Nepal (Terai)Ltd. Raghupati Jute Mills Ltd., Gorakhakali Rubber Udhyog Ltd., Uniliver Nepal Ltd., Nepal Khadya Udhyog Ltd., Fluer Himalayan Ltd., Shree Ram Sugar Mills Ltd, Nepal Bitumin and Barrel Udyog., Himalayan Distillery Ltd., Nepal Lube Oil Ltd,. Soaltee Hotel Ltd., Tara Gaun Regency Hotel Ltd,.Oriental Hotel Ltd., and Yak and Yeti Hotel Ltd. Out of these, Nepal Khadya Udhyog Ltd., Shree Ram Sugars Ltd., Fluer Himalayan Ltd., Raghupati ute Mills Ltd., and Yak and Yeti Hotel has been excluded in the sample due to lack of annual audit report after fiscal year 2011/2012. Remaining seven manufacturing and processing organizations and three hotel organizations has been included in the sample. These data have been collected from Security Board of Nepal, Nepal Stock Exchange and concerned companies. The data collected from 2000/01 to 2014/15 due to lack of annual audit report of fiscal year of 2015/16 of Gorakhkali Rubber Udhyog Ltd. and Nepal Bitumin and Barrel Udyog Ltd. Data have been converted into five-year moving average.

\subsection{Strategy measures}

In line with prior literature, employ key financial statement ratios as an alternative proxy for the identification of companies' strategic position (e.g. Selling \& Stickney 1989; Stickney \& Brown 1998; Banker, Hu, Pavlou, \& Luftman, 2011). Return on assets (ROA) reflects a firm's ability to deploy assets effectively into income producing activities. To further analyze the sources of net income, ROA can be decomposed into two underlying ratios, profit margin (PM) and asset turnover (AT) (e.g. Fairfield \& Yohn 2001; Nissim \& Penman 2001) but calculation of ROA, PM, and At is not included in this paper.

These two ratios represent different aspects of a company' value creation and give insights into a companies' competitive strategy. To achieve high profit margins, companies have to differentiate themselves effectively from competitors so that each company can charge premium prices to their loyal customers. Thus, a high profit margin is often associated with a successful differentiation strategy. On the other hand, a high asset turnover reflects a firm's ability to operate and utilize its resources efficiently to 
generate sales revenue. Therefore high assets turnover reflect a cost leadership strategy (Porter, 1996; Fairfield \& Yohn, 2001). Hence, this study uses five-year moving averages of profit margin and average assets turnover as proxies of the strategic position (differentiation and cost leadership) of selected enterprises.

\subsection{Descriptive statistics}

For describing the various characteristics and dimensions of quantitative data, different tools of descriptive statistics are used. Mean, median, minimum value, maximum value and standard deviation are used for analysis of secondary data.

\subsection{Correlation analysis}

In correlation analysis, the strength of linear relationship among the different variables is measured. Measurement of the strength of relationship between the two quantitative variables, $\mathrm{X}$ and $\mathrm{Y}$ is usually carried out by simple correlation coefficient, denoted by ' $\mathrm{r}$ '. Correlation analysis is useful in exploratory data analysis. It provides some guidelines for selecting independent variables in multiple regression analysis. In correlation analysis in this study, different variables such as profit margin, assets turnover, natural logarithm of change in costs and natural logarithm of change in sales revenue and including influence of different dummy variables are analyzed.

\subsection{Regression analysis}

Different regression models are used to predict the relations of each component. Begin by developing a regression model to evaluate this first research hypothesis on the asymmetric cost behavior based on the generic strategies followed by organizations.

\section{Empirical model}

$\ln \left(\operatorname{Cost}_{\mathrm{i}, \mathrm{t}} / \operatorname{Cost}_{\mathrm{i}, \mathrm{t}-1}\right)=\alpha_{0}+\beta_{1} \ln \left(\operatorname{Rev}_{\mathrm{i}, \mathrm{t}} / \operatorname{Rev}_{\mathrm{i}, \mathrm{t}-1}\right)+\boldsymbol{\beta}_{2} \operatorname{AvgPM}_{\mathrm{i}, \mathrm{t}}+\boldsymbol{\beta}_{3} \operatorname{AvgATO}_{\mathrm{i}, \mathrm{t}}+$ $\boldsymbol{\beta}_{4} \operatorname{Dec}_{\mathrm{i}, \mathrm{t}} \ln \left(\operatorname{Rev}_{\mathrm{i}, \mathrm{t}} / \operatorname{Rev}_{\mathrm{i}, \mathrm{t}-1}\right)+\beta_{5} \operatorname{Dec}_{\mathrm{i}, \mathrm{A}} \operatorname{AvgPM}_{\mathrm{i}, \mathrm{t}} \ln \left(\operatorname{Rev}_{\mathrm{i}, t} / \operatorname{Rev}_{\mathrm{i}, \mathrm{t}-1}\right)+$ $\boldsymbol{\beta}_{6} \operatorname{Dec}_{i, t} \operatorname{Avg} A T O_{i, t} \ln \left(\operatorname{Revi}, t /{ }_{\text {Revi,t-1 }}\right)+\boldsymbol{\beta}_{7} \operatorname{Dec}_{i, t} \operatorname{SucDec}_{i, t} \ln \left(\operatorname{Rev}_{\mathrm{i}, t} / \operatorname{Rev}_{\mathrm{i}, \mathrm{t}-1}+\varepsilon_{\mathrm{i}, \mathrm{t}} \ldots\right.$ (i)

Where, $\ln \left(\operatorname{Cost}_{\mathrm{i}, \mathrm{t}} / \operatorname{Cost}_{\mathrm{i}, \mathrm{t}-1}\right)$ is the natural logarithm of change in costs i.e. five-year moving average of representing selling, general and administrative cost (SGA) and cost of goods sold (COGS) of a firm i in a period $t, \ln \left(\operatorname{Rev}_{\mathrm{i}, \mathrm{t}} / \operatorname{Rev}_{\mathrm{i}, \mathrm{t}-1}\right)$ is the natural logarithm of change in sales revenue representing five-year moving average of a firm i in a period t. $\operatorname{AvgPM}_{i, t}$ 
refers to the five-year moving average of profit margin and it is a result of net profit after tax divided by sales revenue of a firm $i$ in a period $t$. AvgATO $\mathrm{A}_{i, t}$ refers to the five-year moving average of assets turnover rate of firm $i$ in a period $t$ and it is a result of sales divided by total assets of a firm $i$ in a period $t$.

"Dec" is a dummy variable, which equals 1 if the sales of a firm $i$ in a period t decrease compared to the sales in the prior period t-1; otherwise, "Dec" equals zero. SucDeci,t a dummy equal to 1 for firm-period observations when revenue declined in the preceding period; otherwise 0 .

\section{Data analysis and findings}

\subsection{Descriptive statistics}

Table 1 offers descriptive statistics on the strategic variables which are the natural logarithm of change in costs, natural logarithm of change in sales revenue, profit margin, assets turnover rate, interaction of Dec and natural logarithm of change in sales revenue, interaction of Dec, profit margin and natural logarithm of change in sales revenue, interaction of Dec, assets turnover rate and natural logarithm of change in sales revenue and interaction of Dec, SucDec and natural logarithm of change in sales revenue. All data are computed on the basis of five-year moving average.

Table 1

Descriptive statistics

\begin{tabular}{|c|c|c|c|c|c|c|c|}
\hline & Unit & $\mathrm{N}$ & Mean & Median & Std. Deviation & Minimum & Maximum \\
\hline $\ln \left(\operatorname{Cost}_{\mathrm{i}, \mathrm{t}} / \operatorname{Cost}_{\mathrm{i}, \mathrm{t}-1}\right)$ & Ratio & 110 & 0.11342 & 0.10325 & 0.06123 & -0.0423 & 0.30773 \\
\hline $\ln \left(\operatorname{Rev}_{\mathrm{i}, t} / \operatorname{Rev}_{\mathrm{i}, \mathrm{t}-1}\right)$ & “ & 110 & 0.11615 & 0.12312 & 0.07961 & -0.0517 & 0.32324 \\
\hline $\operatorname{AvgPM} M_{i, t}$ & “ & 110 & 0.07723 & 0.0312 & 0.1032 & 0.00031 & 0.58652 \\
\hline $\operatorname{Avg} \mathrm{ATO}_{\mathrm{i}, \mathrm{t}}$ & “ & 110 & 2.53342 & 0.777 & 5.46312 & 0.13742 & 27.13413 \\
\hline $\operatorname{Dec}_{\mathrm{i}, \mathrm{t}} \ln \left(\operatorname{Rev}_{\mathrm{i}, t} / \operatorname{Rev}_{\mathrm{i}, \mathrm{t}-1}\right)$ & & 110 & -0.003 & 0 & 0.00661 & -0.0518 & 0 \\
\hline 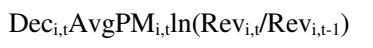 & & 110 & -0.0003 & 0 & 0.00079 & -0.0082 & 0 \\
\hline $\operatorname{Dec}_{\mathrm{i}, \mathrm{A}} \operatorname{Avg} \mathrm{ATO}_{\mathrm{i}, \mathrm{t}} \ln \left(\operatorname{Rev}_{\mathrm{i}, \mathrm{t}} / \operatorname{Rev}_{\mathrm{i}, \mathrm{t}-1}\right)$ & & 110 & -0.0014 & 0 & 0.00432 & -0.0261 & 0 \\
\hline $\operatorname{DecSucitDec}_{\mathrm{i}, \mathrm{t}} \ln \left(\operatorname{Rev}_{\mathrm{i}, \mathrm{t}} / \operatorname{Rev}_{\mathrm{i}, \mathrm{t}-1}\right.$ & & 110 & -0.003 & 0 & 0.00712 & -0.0526 & 0 \\
\hline
\end{tabular}

Mean (S.D.) of natural logarithm of change in costs is 0.11342 (0.06123), minimum and maximum value is -0.0423 and 0.30773 respectively. Mean (S.D.) of natural logarithm of change in sales revenue is $0.11615(0.07961)$, minimum and maximum value is -0.0517 and 0.32324 respectively. Mean (S.D.) of profit margin is $0.07723(0.1032)$, minimum 
and maximum value is 0.00031 and 0.58652 respectively. Mean (S.D.) of assets turnover rate is 2.53342 (5.46312), minimum and maximum value is 0.13742 and 27.13413 respectively. Mean (S.D.) of interaction of Dec and natural logarithm of change in sales revenue is $-0.003(0.0061)$, minimum and maximum value is -0.0518 and nil respectively.

Similarly, mean (S.D.) of interaction of Dec, average profit margin and change in natural logarithm of sales ratio is -0.0003 (0.00079), minimum and maximum value is -0.0082 and 0 respectively. Mean (S.D.) of interaction of Dec, average total assets turnover rate and natural logarithm of change in sales ratio is -0.0014 (0.00432). Minimum and maximum value is -0.0261 and 0 respectively. Mean (S.D.) of interaction of DecSucDec natural logaritham of change in sales ratio is $-0.003(0.00712)$. Minimum and maximum value is -0.0526 and nil respectively. Number of observation of firm year is 110 .

\subsection{Correlation analysis}

Table 2 presents the result of correlation analysis of the strategic variables which are the natural logarithm of change in costs, natural logarithm of change in sales revenue, profit margin, assets turnover rate, interaction of Dec and natural logarithm of change in sales revenue, interaction of Dec, profit margin and natural logarithm of change in sales revenue, interaction of Dec, assets turnover rate and natural logarithm of change in sales revenue and interaction of Dec, SucDec and natural logarithm of change in sales revenue.

Table 2

\section{Correlation analysis}

\begin{tabular}{|c|c|c|c|c|c|c|c|c|}
\hline & $\begin{array}{l}\ln \left(\operatorname{Cost}_{\mathrm{i}, \mathrm{t}} / \mathrm{C}\right. \\
\left.\text { ost }_{\mathrm{i}, \mathrm{t}-1}\right)\end{array}$ & $\begin{array}{l}\ln \left(\operatorname{Rev}_{\mathrm{i}, \mathrm{t}} /\right. \\
\left.\operatorname{Rev}_{\mathrm{i}, \mathrm{t}-1}\right)\end{array}$ & $\operatorname{AvgPM}_{i, t}$ & $\begin{array}{l}\operatorname{AvgA} \\
\mathrm{TO}_{\mathrm{i}, \mathrm{t}}\end{array}$ & $\begin{array}{l}\operatorname{Dec}_{i, t} \ln \\
\left(\operatorname{Rev}_{i, t} /\right. \\
\left.\operatorname{Rev}_{i, t-1}\right)\end{array}$ & $\begin{array}{l}\operatorname{Dec}_{\mathrm{i}, \mathrm{t}} \text { Avg } \\
\mathrm{PM}_{\mathrm{i}, \mathrm{t}} \ln (\mathrm{R} \\
\mathrm{ev}_{\mathrm{i}, \mathrm{t}} / \operatorname{Rev}_{\mathrm{i}, \mathrm{t}} \\
-1)\end{array}$ & $\begin{array}{l}\operatorname{Dec}_{\mathrm{i}, \mathrm{t}} \mathrm{Avg} \\
\mathrm{ATO}_{\mathrm{i}, \mathrm{t}} \ln ( \\
\operatorname{Rev}_{\mathrm{i}, \mathrm{t}} / \operatorname{Re} \\
\left.\mathrm{v}_{\mathrm{i}, \mathrm{t}-1}\right)\end{array}$ & $\begin{array}{l}\text { DecSucit } \\
\operatorname{Dec}_{\mathrm{i}, \mathrm{t}} \ln (\mathrm{R} \\
\mathrm{ev}_{\mathrm{i}, \mathrm{t}} / \operatorname{Rev}_{\mathrm{i}, \mathrm{t}} \\
-1\end{array}$ \\
\hline $\ln \left(\operatorname{Cost}_{\mathrm{i}, \mathrm{t}} / \operatorname{Cost}_{\mathrm{i}, \mathrm{t}-1}\right)$ & 1 & & & & & & & \\
\hline $\ln \left(\operatorname{Rev}_{\mathrm{i}, t} / \operatorname{Rev}_{\mathrm{i}, \mathrm{t}-1}\right)$ & $.796^{*}$ & 1 & & & & & & \\
\hline $\operatorname{AvgPM}_{\mathrm{i}, \mathrm{t}}$ & $0.212 * * *$ & 0.06 & 1 & & & & & \\
\hline $\operatorname{AvgATO}_{\mathrm{i}, \mathrm{t}}$ & $.312 * *$ & 0.131 & $.613 *$ & 1 & & & & \\
\hline $\operatorname{Dec}_{\mathrm{i}, \mathrm{t}} \ln \left(\operatorname{Rev}_{\mathrm{i}, \mathrm{t}} / \operatorname{Rev}_{\mathrm{i}, \mathrm{t}-1}\right)$ & $.421 *$ & $.453^{*}$ & 0.132 & 0.082 & 1 & & & \\
\hline $\begin{array}{l}\operatorname{Dec}_{i, t} \operatorname{AvgPM}_{i, t} \ln \left(\operatorname{Rev}_{\mathrm{i}, \mathrm{t}}\right. \\
\left./ \operatorname{Rev}_{\mathrm{i}, \mathrm{t}-1}\right)\end{array}$ & $-.205^{* *}$ & $-.261 * *$ & $-0.16^{* * *}$ & -0.114 & $-.612 *$ & 1 & & \\
\hline $\begin{array}{l}\operatorname{Dec}_{i, t} \operatorname{AvgATO}{ }_{i, t} \ln (\operatorname{Re} \\
\left.v_{i, t} / \operatorname{Rev}_{i, t-1}\right)\end{array}$ & $.365^{*}$ & $.491 *$ & 0.031 & 0.029 & $.953 *$ & $-.512 *$ & 1 & \\
\hline $\begin{array}{l}\operatorname{DecSucitDec}_{\mathrm{i}, \mathrm{t}} \ln \left(\operatorname{Rev}_{\mathrm{i}, \mathrm{t}}\right. \\
/ \operatorname{Rev}_{\mathrm{i}, \mathrm{t}-1}\end{array}$ & $.461 *$ & $.462 *$ & 0.071 & 0.088 & $.981 *$ & $-.616^{*}$ & $.926 *$ & 1 \\
\hline
\end{tabular}

Note: * Significant at 0.01 levels $* *$ Significant at 0.05 levels $* * *$ Significant at 0.10 levels Pearson correlation 
Correlation between natural logarithm of change in costs and natural logarithm of change in sales revenue is high degree of positive at 1 percent level. Correlation between natural logarithm of change in costs with profit margin and with assets turnover rate is low degree of positive at 10 percent and 5 percent level respectively. Correlation between profit margin and assets turnover rate is moderate degree of positive correlation at 1 percent level. Correlation coefficient between natural logarithm of change in cost ratio and interaction of Dec, profit margin and natural logarithm of change in sales ratio is low degree of inverse relation which is significant at 5 percent level but correlation coefficient between natural logarithm of change in cost ratio with interaction of Dec. natural logarithm of change in sales ratio; interaction of DecSucDec natural logaritham of change in sales ratio; interaction of Dec, assets turnover rate and natural logarithm of change in sales ratio is low degree of positive relation at 1 percent level.

\subsection{Regression analysis}

A relationship between natural logarithm of change in costs, natural logarithm of change in sales revenue, interaction of Dec, profit margin and natural logarithm of change in sales revenue, interaction of Dec, assets turnover rate and natural logarithm of change in sales revenue can be expressed by the following formula:

$\ln \left(\operatorname{Cost}_{\mathrm{i}, \mathrm{t}} / \operatorname{Cost}_{\mathrm{i}, \mathrm{t}-1}\right)=\alpha_{0}+\beta_{1} \ln \left(\operatorname{Rev}_{\mathrm{i}, \mathrm{t}} / \operatorname{Rev}_{\mathrm{i}, \mathrm{t}-1}\right)+\beta_{2} \operatorname{Dec}_{\mathrm{i}, \mathrm{A}} \operatorname{AvgPM}_{\mathrm{i}, \mathrm{l}} \ln \left(\operatorname{Rev}_{\mathrm{i}, \mathrm{t}} / \operatorname{Rev}_{\mathrm{i}, \mathrm{t}-1}\right)+$ $\boldsymbol{\beta}_{3} \operatorname{Dec}_{\mathrm{i}, \mathrm{t}} \operatorname{Avg} \mathrm{ATO}_{\mathrm{i}, \mathrm{t}} \ln \left(\right.$ Revi,t/Revi,t-1) $+\varepsilon_{\mathrm{i}, \mathrm{t}} \ldots$ (i)

Where, $\ln \left(\operatorname{Cost}_{\mathrm{i}, \mathrm{t}} / \operatorname{Cost}_{\mathrm{i}, \mathrm{t}-1}\right)=$ Natural logarithm of five-year moving average of sum of cost of goods sold + selling, general and administrative expenses of a firm $i$ in a period $t$ divided by natural logarithm of five-year moving average of sum of cost of goods sold + selling, general and administrative expenses of a firm $\mathrm{i}$ in a period $\mathrm{t}-1$.

$\left.\ln \left(\operatorname{Rev}_{\mathrm{i}, \mathrm{t}} / \operatorname{Rev}_{\mathrm{i}, \mathrm{t}-1}\right)\right)=$ Natural logarithm of five-year moving average of sales revenue of a firm $i$ in a period $t$ divided by natural logarithm of five-year moving average of sales revenue of a firm $i$ in a period $t-1$

$\operatorname{Dec}_{i, t} \operatorname{AvgPM}_{\mathrm{i}, \mathrm{t}} \ln \left(\right.$ Revi,t/Revi,t-1) = Interaction of $\operatorname{Dec}_{\mathrm{i}, \mathrm{t}}$ ("Dec" is a dummy variable, which equals 1 if the sales of a firm $i$ in a period $t$ decrease compared to the sales in the prior year t-1; otherwise, "Dec" equals zero of a firm i in a period t), $\operatorname{AvgPM}_{\mathrm{i}, \mathrm{t}}$ (Five-year moving average of net profit after tax of a firm $i$ in a period $t)$ and $\ln \left(\operatorname{Rev}_{\mathrm{i}, t} / \operatorname{Rev}_{\mathrm{i}, t-1}\right)$ is natural logarithm of five-year moving average of sales revenue of a firm $i$ in a period $t$ 
divided by natural logarithm of five-year moving average of sales revenue of a firm i in a period $\mathrm{t}-1$.

$\operatorname{Dec}_{i, t} \operatorname{AvgATO}_{i, t} \ln \left(\operatorname{Rev}_{i, t} / \operatorname{Rev}_{i, t-1}\right)=$ Interaction of $\operatorname{Dec}_{i, t}, \operatorname{AvgATO}_{i, t}$ (Five-year moving average of assets turnover ratio of a firm $i$ in a period $t$ which is calculated by sales/total assets) and $\ln \left(\operatorname{Rev}_{\mathrm{i}, \mathrm{t}} / \operatorname{Rev}_{\mathrm{i}, \mathrm{t}-1}\right)$

$\alpha_{0}=$ constant value, $\beta 1, \beta 2, \beta 3$ are slopes of independent variables and $\varepsilon i t \ldots$ is error term.

Glejser test has been used to detect heteroscedasticity problem and this model is not free from this problem. Dependent and all independent variables have been divided by unstandardized predicted variables to minimize such problem. After completion of remedial measure, regression model is $\operatorname{Rem} \ln \left(\operatorname{Cos}_{\mathrm{t}, \mathrm{t}} / \operatorname{Cost}_{\mathrm{i}, \mathrm{t}-1}\right)=\alpha_{0}+\operatorname{Rem} \beta_{1} \ln \left(\operatorname{Rev}_{\mathrm{i}, \mathrm{t}} / \operatorname{Rev}_{\mathrm{i}, \mathrm{t}-}\right.$ $\left.{ }_{1}\right)+\operatorname{Rem}_{2} \operatorname{Dec}_{\mathrm{i}, \mathrm{t}} \operatorname{AvgPM}_{\mathrm{i}, \mathrm{t}} \ln \left(\operatorname{Rev}_{\mathrm{i}, \mathrm{t}} / \operatorname{Rev}_{\mathrm{i}, \mathrm{t}-1}\right)+\operatorname{Rem} \beta_{3} \operatorname{Dec}_{\mathrm{i}, \mathrm{A}} \mathrm{Avg}_{\mathrm{ATO}} \mathrm{O}_{\mathrm{i}, \mathrm{t}} \ln \left(\operatorname{Rev}_{\mathrm{i}, \mathrm{t}} / \operatorname{Rev}_{\mathrm{i}, \mathrm{t}-1}\right)+$ $\varepsilon_{\mathrm{i}, \mathrm{N}} \ldots$

The computed values of the regression equation for the selected enterprises are presented in table 3 .

Table 3

Regression result of natural logarithm of change in costs, natural logarithm of change in sales revenue, Interaction of Dec, profit margin and natural logarithm of change in sales revenue and interaction of Dec, assets turnover rate and natural logarithm of change in sales revenue

\begin{tabular}{|c|c|c|c|c|c|}
\hline $\begin{array}{c}\ln \left(\operatorname{Cos}_{\mathrm{ti}, \mathrm{t}} / \operatorname{Cost}_{\mathrm{i}},\right. \\
\mathrm{t}-1)\end{array}$ & $=\beta_{0}$ & $\begin{array}{c}\beta_{1} \\
\ln \left(\operatorname{Rev}_{\mathrm{i}, \mathrm{t}} / \operatorname{Rev}_{\mathrm{i}, \mathrm{t}}\right. \\
11\end{array}$ & $\begin{array}{c}\boldsymbol{+}_{\mathbf{2}} \\
\operatorname{Dec}_{\mathrm{i}, \mathrm{t}} \operatorname{AvgPM}_{\mathrm{i}, \mathrm{t}} \ln \left(\operatorname{Rev}_{\mathrm{i}, \mathrm{t}} /\right. \\
\left.\operatorname{Rev}_{\mathrm{i}, \mathrm{t}-1}\right)\end{array}$ & $\begin{array}{c}\beta_{3} \\
\operatorname{Dec}_{\mathrm{i}, \mathrm{t}} \operatorname{Avg}_{\mathrm{ATO}} \mathrm{O}_{\mathrm{i}, \mathrm{l}} \ln \left(\operatorname{Rev}_{\mathrm{i}, \mathrm{t}} \mathrm{I}\right. \\
\left.\operatorname{Rev}_{\mathrm{i}, \mathrm{t}-1}\right)\end{array}$ & $\begin{array}{l}\varepsilon i, \mathrm{t} \\
\ldots\end{array}$ \\
\hline $\begin{array}{l}\text { Intercept/Coef } \\
\text { ficients }\end{array}$ & $-1.642 *$ & $2.612 *$ & $-16.342 *$ & $1.792^{*}$ & \\
\hline S.E & 0.234 & 0.223 & 2.912 & 0.472 & \\
\hline $\mathrm{T}$ & -7.612 & 11.824 & -5.142 & 3.512 & \\
\hline VIF & & 2.21 & 2.212 & 3.168 & \\
\hline \multicolumn{5}{|c|}{$\begin{array}{l}\mathrm{R}^{2}=0.725 \quad \mathrm{~F}=120.279 * \\
\text { Number of Observations }=110, \quad \text { Note: } * \text { Significant at } 0.01 \text { level } \\
* * \text { Significant at } 0.05 \text { levels } * * * \text { Significant at } 0.10 \text { levels }\end{array}$} & \\
\hline
\end{tabular}

The explanatory power of the model is reasonably high given as the $\mathrm{R}^{2}$ is estimated at 72.5 percent. The F-statistic is also statistically significant at 1 percent. The value of DW 2.011 indicates that there is no autocorrelation. Value of VIF of independent variables is 
less than 10. Hence, all independent variables indicate that there is no multicollinearity problem i.e. there is no correlation between three independent variables. Data is normally distributed. So, regression model fulfil the regression assumptions.

Coefficient values of all independent variables are statistically significant at 1 percent level. Coefficient value of $\ln \left(\operatorname{Rev}_{\mathrm{i}, \mathrm{t}} / \operatorname{Rev}_{\mathrm{i}, \mathrm{t}-1}\right)$ and $\operatorname{Dec}_{\mathrm{i}, \mathrm{t}} \operatorname{Avg}_{\mathrm{ATO}} \mathrm{O}_{\mathrm{i}, \mathrm{l}} \ln \left(\operatorname{Rev}_{\mathrm{i}, \mathrm{t}} / \operatorname{Rev}_{\mathrm{i}, \mathrm{t}-1}\right)$ is positive but coefficient value of $\operatorname{Dec}_{\mathrm{i}, \mathrm{t}} \mathrm{AvgPM}_{\mathrm{i}, \mathrm{t}} \ln \left(\operatorname{Rev}_{\mathrm{i}, \mathrm{t}} / \operatorname{Rev}_{\mathrm{i}, \mathrm{t}-\mathrm{1}}\right)$ is negative. The empirical results as per prior expectation support hypothesis one i.e. cost stickiness of firms pursuing a differentiation strategy is higher than that of firms following a low cost strategy. High $\operatorname{Avg}(\mathrm{PM})$ as a proxy for a differentiation strategy and high avg(ATO) as a proxy for a cost leadership strategy. The result is similar with Banker, et al., 2013.

\section{Conclusion}

The analysis shows that the enterprises adopting higher gross profit margin are pursuing differentiation strategy whereas, higher investment on property, plant and equipment along with their existing value indicates that they are following cost leadership strategy. Coefficient value of independent variable interaction of Dec i.e. dummy variable, average profit margin and natural logarithm of change in sales ratio with dependent variable natural logarithm of change in cost ratio is negative. Coefficient value of another independent variable interaction of Dec i.e. dummy variable, average assets turnover rate and natural logarithm of change in sales ratio and dependent variable natural logarithm of change in cost ratio is positive. Hence, it is as per prior hypothesized i.e. this study has supported (if other thing is remaining the same) cost stickiness of firms pursuing a differentiation strategy is higher than that of firms following a low cost strategy. 


\section{REFERENCES}

Anderson, M.C., Banker, R.D., \& Janakiraman, S.N. (2003). Are selling, general, and administrative costs sticky? Journal of Accounting Research, 41(1), 47-63.

Banker, R.D., \& Byzalov, D., (2013). Asymmetric cost behavior (Working paper). Temple University.

Banker, R. D., Byzalov, D., Ciftci, M., \& Mashruwala, R., (2013). The moderating effect of prior sales changes on asymmetric cost behavior (Working paper). Temple University.

Banker, R.D., Hu, N., Pavlou, P.A., \& Luftman, J., (2011). CIO reporting structure, strategic positioning, and firm performance. MIS Quarterly, 35(2), 487-504.

Bentley, K., Omer, T., \& Sharp, N. (2012). Business strategy, financial reporting irregularities, and audit effort. Contemporary Accounting Research, doi:10.1111/j.1911-3846.2012.01174.x.

Cooper, R., \& Kaplan, R. (1998). The design of cost management system: Text, cases and readings. Upper Saddle River, NJ: Prentice Hall.

Chen, C., H. Lu \& T. Sougiannis (2012). The agency problem, corporate governance, and the asymmetrical behavior of selling, general, and administrative costs. Contemporary Accounting Research, 29 (1), 252-282.

Dierynck, B., Landsman, W., \& Renders, A., (2012). Do managerial incentives drive cost behavior? Evidence about the role the zero earnings benchmark for labor cost behavior in private Belgian firms. The Accounting Review, 87, 1219-1246.

Fairfield, P. M., \& Yohn, T. L. (2001). Using asset turnover and profit margin to forecast changes in firm profitability. Review of Accounting Studies, 6, 371-385.

Hambrick, D. C. (1982). Environmental scanning and organizational strategy. Strategic Management Journal, Vol. 3.

Ittner, C.D., Larcker, D.F., \& Rajan, M.V.(1997). The choice of performance measures in annual bonus contracts. The Accounting Review, 7292, 231-255.

Kama, I., \& Weiss, D., (2013). Do earnings targets and managerial incentives affect sticky costs? Journal of Accounting Research, 51, 201-224. 
Miles, R.E., \& Snow, C.C. (1978). Organizational strategy, structure, and process, McGraw-Hill, New York, NY.

Miller, D. (1986). Configurations of strategy and structure: Towards a synthesis. Strategic Management Journal, 7(3), 233-249.

Miller, D. (1988). Relating Porter's business strategies to environment and structure: Analysis and performance implications. The Academy of Management Journal, 31(2), 280-308.

Nissim, D., Penman, S. (2001). Ratio analysis and equity valuation: From research to practice. Review of Accounting Studies, 6, 109-154.

Noreen. E. (1991). Conditions under which activity-based cost systems provide relevant costs. Journal of Management Accounting Research, 3, 159-168.

Peteraf, M. (1993). The cornerstones of competitive advantage: A resource-based view. Strategic Management Journal, 14(3), 179-191.

Porter, M.E. (1980). Competitive Strategy, Free Press, New York, NY.

Porter, M.E. (1985). Competitive advantage: Creating and sustaining superior performance. Free Press, New York, NY.

Porter, M. E. (1991). Towards a dynamic theory of strategy. Strategic Management Journal, 12, 95-117.

Porter, M.E (1996). What is strategy? Harvard Business Review. Nov-Dec, 59-79.

Selling, T. I., \& Stickney, C. P. (1989). The effects of business environment and strategy on a firm's rate of return on assets. Financial Analysts Journal, 45, 43-68.

Stickney, C., \& Brown, P. (1998). Financial reporting and statement analysis (4th ed.). New York: Dryden Press.

Weiss, D. (2010). Cost behavior and analysts earnings forecasts. The Accounting Review, 85 (4), 1441-1471.

White, R.E. (1986). Generic business strategies, organizational context, and performance: An empirical investigation. Strategic Management Journal, 7(2), 217-231. 